\title{
Induction of Ovulation in Mangalarga Marchador Mares by hCG or GnRH
}

\author{
José Carlos Ferreira-Silva', Pábola Santos Nascimento', Marcelo Tigre Moura', Sarah Romini Lima Basto', \\ Marlon Vasconcelos Azevedo ${ }^{2}$, Jorge Motta Rocha ${ }^{3}$, José Pompeu Santos Filho ${ }^{4} \&$ Marcos Antonio Lemos Oliveira'
}

\begin{abstract}
Background: Induction of ovulation is a key procedure for horse assisted reproduction technologies, such as for artificial insemination (AI) and embryo transfer. The application of hCG remains as the primary ovulation-inducing agent for horse assisted reproduction, but alternatives are in demand to avoid its adverse effects, such as loss of ovulation-inducing efficiency over multiple applications by hCC-antibody production. Despite reports on alternative ovulation-inducing agents, pair-wise comparisons of such agents under similar conditions have been limited. Under such scenario, the work was aimed to determine the efficiency of both hCG and Buserelin at inducing ovulation in Mangalarga Marchador mares raised in the Northeast of Brazil under an AI program.

Materials, Methods \& Results: Mares were initially selected based on their reproductive performance, the absence of clinical-reproductive alterations and adequate body condition score. Mares in diestrus were randomly distributed in three experimental conditions, received $5 \mathrm{mg}$ of Dinoprost and were monitored daily for estrus detection. After estrus detection, ovaries were monitored by ultrasonography, in 12-h intervals, until the follicle reached $35 \mathrm{~mm}$. At this time-point, ovulation was induced with $0.042 \mathrm{mg}$ of Buserelin endovenously, with 3,000 IU hCG by an intramuscular shot, and control mares received $2 \mathrm{~mL}$ of saline solution, also by an intramuscular shot. Both $\mathrm{hCG}$ and Buserelin displayed similar efficiencies $(P>0.05)$ for induction of ovulation and that both agents were effective $(P<0.05)$ for such purpose, since greater percentages $(P<0.05)$ of induction on mares treated from those of the control. Moreover, the total number of ovulations in mares treated at the end of the experiment was not different $(P>0.05)$ from those found in the Control. All ovulations occurred within a 72-h period after treatment. It can be observed that in mares treated with hCG or Buserelin, ovulations occurred both in more mares $(P<0.05)$ and at earlier time-points than mares from the control. It is also possible to note that pregnancy was not different $(P>0.05)$ between hCG and Buserelin groups, and that pregnancy of mares treated with ovulation-inducing factors was similar to the control.

Discussion: The majority of ovulations in mares occurred within initial 48-h after treatment for both hCG and GnRH, suggesting a similar potential for horse assisted reproduction. Both $\mathrm{hCG}$ and Buserelin are two commonly used agents for induction of ovulation in mares. As described here, the majority of ovulations occurred within initial 48-h after treatment, a fact which can be attributed to hCG and GnRH activity, since it can happen in intervals from 36 to 48-h after treatment. Pregnancy rates did not differ among groups. These results are under the working hypothesis that hCG and Buserelin would display similar efficiencies on pregnancy rates. Despite the understanding of hCG activity on induction of ovulation due to its high specificity toward LH receptors and results from a direct effect on diminishing estradiol concentration, increasing $\mathrm{LH}$, and further inducing ovulation within 48-h after treatment. In contrast, Buserelin has a similar functional property but acts upon LH synthesis and its release. In conclusion, ovulation in mares can be induced with both hCG and Buserelin, and both ovulation-inducing agents do not affect pregnancy rates.
\end{abstract}

Keywords: gonadotropin, releasing factor, ovary, follicle, corpus luteum. 


\section{INTRODUCTION}

The duration of the estrogenic phase in horses does not allow to predict the exact moment of ovulation [14], and follicle growth monitoring is required for ovulation assessment $[3,15]$. Therefore, ovulationinducing agents are investigated aiming to increase both artificial insemination (AI) and embryo transfer efficiencies [3,27,29].

The hCG was the first ovulation-inducing agent and remains as the most widely used in mares [30]. Its structure resembles the LH protein, a fact which has suggested that its ovulation-inducing properties result from a direct effect on diminishing estradiol concentration, increasing $\mathrm{LH}$, and ovulation within 48 -h after treatment $[3,16,40]$. It is advisable that when the follicle reaches $35 \mathrm{~mm}$, hCG should be used for induction of ovulation [7]. However, there is some controversy that its usage by repeated means may affect mare fertility $[5,12,17,21,37]$. This detrimental effect may be caused by the formation of antibodies against hCG [12,21,33].

The GnRH is synthesized in the hypothalamus, and its release in pulses stimulates the synthesis and release of both LH and FSH by the anterior pituitary [22]. The GnRH is a natural ovulation-inducing factor, although it has a short half-life [34]. The synthetic analogs of GnRH such as Buserelin [6,17], Deslorelin $[1,3,4]$, and Histrelin [26,30,39], have greater potency and longer half-life confers greater structural and metabolic stability than its natural form [24]. Collectively, all these compounds have been considered as capable of inducing ovulation in mares. Thus, the work aimed to determine the efficiency of both hCG and Buserelin at inducing ovulation in Mangalarga Marchador mares raised in the Northeast of Brazil under an AI program.

\section{MATERIALS AND METHODS}

\section{Experimental location}

The experiment was conducted in Limoeiro, Pernambuco State, Brazil. The farm is located in the following geographic coordinates, $7^{\circ} 52$ ' 29' $\mathrm{S}$ of latitude and $35^{\circ} 27^{\prime} 01^{\prime \prime} \mathrm{W}$ of longitude. The mean annual temperature is $24^{\circ} \mathrm{C}$, and quantum of rain reaches $1,248 \mathrm{~mm}^{3}$.

\section{Animal selection}

Mares selected for the experiment as donors and recipients were pluriparous, non-lactating and of the Mangalarga Machador breed, with age ranging from 5 to 15 years and body weight from 450 to 550 $\mathrm{kg}$. Mares were subject to a semi-extensive pasturing system, thus maintained in cultivated pastures (Digitaria decumbes) and had free access to mineralized salt (Suprafós $\left.73^{\circledR}\right)^{1}$ and water. Moreover, mares were further supplemented with hay (Cynodon spp.), Alfalfa (Medicago sativa) and $4 \mathrm{~kg}$ commercial palletized horse food $\left(\text { Corcelina }^{\circledR}\right)^{2}$.

Mare selection was performed by body condition score evaluation, that varied from 5 to 7 , in a 1 to 9 scale, as established by others [18]. Their selection also considered the reproductive performance, clinical exams, and gynecologic examination by ultrasonography (Aquila Pro $\left.{ }^{\circledR}\right)^{3}$, equipped with a linear multifrequency transducers (6 and $8 \mathrm{MHz}$ ) for identification of the presence of possible endometrial alterations that may affect fertility, as previously suggested [38].

\section{Animal management}

Mares in diestrus $(n=60)$ were randomly and equally distributed into three experimental conditions, received $5 \mathrm{mg}$ of Dinoprost $\left(\text { Lutalyse }^{\circledR}\right)^{4}$ by an intramuscular (IM) shot. After the application of this luteolytic agent, mares were observed daily for estrus detection. Upon estrus detection, ovaries were monitored by ultrasonography in 12-h intervals, until the follicle reached $35 \mathrm{~mm}$ when ovulation was induced by candidate inducers.

One group of mares $(n=20)$ received 0.042 mg Buserelin acetate $\left(\text { Conceptal }{ }^{\circledR}\right)^{5}$ endovenously, another group $(\mathrm{n}=20)$ was treated with $3,000 \mathrm{IU}$ hCG $\left(\text { Vetecor }^{\circledR}\right)^{6}$ by IM shot, and the control $(\mathrm{n}=20)$ was treated with $2 \mathrm{~mL}$ of saline solution $(0.9 \%, \mathrm{NaCl})^{7}$ by IM shot. The ultrasonography monitoring was performed until ovulation detection. Ovulations were considered induced when detected until day 3 (72-h) after its induction.

Mares were subject to AI at 48-h intervals until ovulation using cooled semen $\left(4^{\circ} \mathrm{C}\right)$ at the concentration of $500 \times 10^{6}$ viable sperm cells. Pregnancy diagnosis was performed on days 30 and 60 after AI, according to previous work [32].

\section{Statistical analysis}

The statistical analysis of binomial data was presented as percentages were performed by the chisquare test with Yates correction [31]. The significance level was $5 \%$. 


\section{RESULTS}

The Table 1 shows that hCG and Buserelin display the same efficiency $(P>0.05)$ for induction of ovulation and that both substances are effective $(P<0.05)$ for this purpose, since greater percentages $(P<0.05)$ of induction on mares treated from those of the control. However, the total number of ovulations of mares treated at the end of the experiment was not different $(P>0.05)$ from those found in the Control.
The Figure 1A contains the distribution of ovulations that occurred until 72-h after treatment. It can be noted that in mares treated with hCG or Buserelin, ovulations occurred both in more mares $(P<0.05)$ and at earlier time-points than mares from the control. Figure 1B shows that pregnancy was not different $(P>0.05)$ between hCG and Buserelin groups, and that pregnancy of mares treated with ovulation-inducing factors was similar to the control.

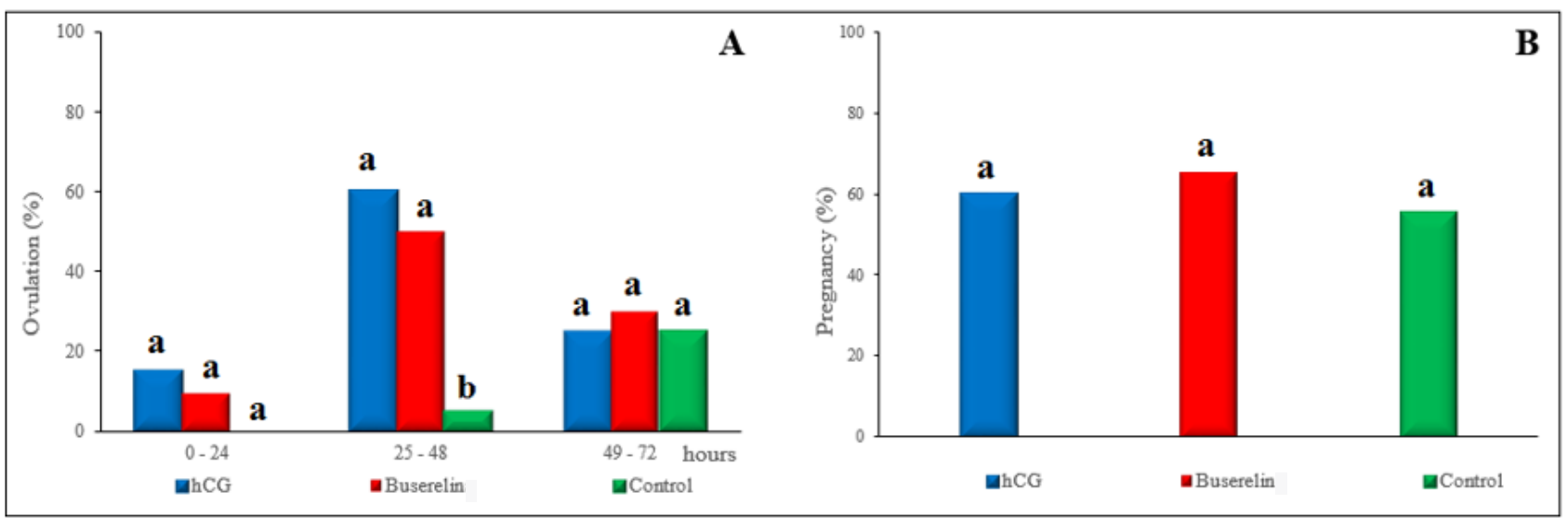

Figure 1. Distribution of ovulations within $72 \mathrm{~h}$ after treatment with ovulation-inducing agents (A) and total pregnancy after artificial insemination (B). Different letters on same time-period indicate statistical significance $(P<0.05)$.

Table 1. Induction of ovulation in Manga Larga Marchador mares subject to hCG or Buserelin treatment.

\begin{tabular}{cccc}
\hline & \multicolumn{3}{c}{ Ovulatory Treatment } \\
\cline { 2 - 4 } Ovulation (Day) & $\mathrm{hCG}$ & Buserelin & Control \\
& $\mathrm{n} / \mathrm{n}(\%)$ & $\mathrm{n} / \mathrm{n}(\%)$ & $\mathrm{n} / \mathrm{n}(\%)$ \\
\hline $0-3$ & $20 / 20(100.0)^{\mathrm{A}}$ & $18 / 20(90.0)^{\mathrm{A}}$ & $6 / 20(30.0)^{\mathrm{B}}$ \\
$>3$ & - & $2 / 20(10.0)^{\mathrm{A}}$ & $12 / 20(60.0)^{\mathrm{B}}$ \\
\hline Total & $20 / 20(100.0)^{\mathrm{A}}$ & $20 / 20(100.0)^{\mathrm{A}}$ & $18 / 20(90.0)^{\mathrm{B}}$ \\
\hline
\end{tabular}

Different letters on same line indicate statistical significance $(P<0.05)$.

\section{DISCUSSION}

Both hCG and Buserelin continue as two commonly used agents for induction of ovulation in mares [26]. As described here, the majority of ovulations occurred within initial 48-h after treatment, a fact which can be attributed to hCG and GnRH activity, since it can happen in intervals from 36 to 48-h after treatment [13].

Except for one reference [2] that obtained $100 \%$ ovulation rate in mares treated with hCG, other reports $[8,26]$ found similar percentages to those described above. It is possible that divergences among results of some authors can be attributed to the period of the breeding season, since such ovulation-inducing agents are less efficient at the beginning and the end of the aforementioned season, possibly due to shorter exposure to sunlight [5].

According to Wilson et al. [40], similarities in the molecular structure and binding of hCG to LH receptors has suggested that its ovulation-inducing properties in mares result from a direct effect that mimics the mechanisms that increase LH concentration. Gunther et al. [16] verified that hCG reduces estradiol and increases LH concentrations, thus inducing ovulation after 48-h of treatment. This fact explains why 
the majority of mares treated with hCG, as described above, have ovulated within 25 to 48 -h after receiving this gonadotropin. It may be possible that ovulations that occurred before this period did not correspond to the hormone therapy. This fact is based on the fact that as ovulations within initial 24-h after treatment did not happen due to this ovulation-inducing agent, are spontaneous ovulations determined by the LH endogenous peak, as previously suggested [21].

The initial usage of natural GnRH to induce ovulation did not yield exciting results, due to its low potency and short half-life [34]. The advent of its synthetic analogs, with greater activity and prolonged half-life, the perspective of its application changed completely. In Brazil, Deslorelin is currently being used for induction of single, or more particularly, multiple ovulations $[3,4,25,35,36,38]$. As described here, Buserelin was considered effective since induced ovulation frequency did not differ from the obtained with hCG, and were also not different from those reported by authors using this agent $[6,9,26]$ or other synthetic analogs $[2,10]$.

The knowledge of ovulation-inducing agents commercially available, mare individual evaluation and adequate management practices are fundamental for successful hormone therapy [13]. The results for induction of ovulation described here can be credited to several factors, in particular to some aspects related to the mare, such as adequate body condition score, estrus cycle regularity, and absence of previous reproductive problems. Another element that also contributed to such results was to administer both ovulation-inducing agents at the moment where follicles had reached at least $35 \mathrm{~mm}$ [28].

Pregnancy rates did not differ from those reported by several groups $[11,19,20,23]$. Moreover, these pregnancy results are in agreement with the initial hypothesis that hCG and Buserelin would show similar efficiencies. Despite the knowledge on hCG for induction of ovulation due to its high specificity toward the $\mathrm{LH}$ receptors, Buserelin is responsible for stimulating LH synthesis and its release. Therefore, despite in an indirect fashion, it exerts a relevant effect on the induction of ovulation. Moreover, the results described here can also be due to mare selection based on the reproductive performance, absence of clinical-reproductive alterations, adequate body condition score, regularity in cyclicity, and estrus duration.

\section{CONCLUSIONS}

In conclusion, ovulation in mares can be induced with both hCG and Buserelin, and both ovulation-inducing agents do not affect pregnancy rates.

\section{MANUFACTURERS}

${ }^{1}$ Supranor Nutrição Animal. Recife, PE, Brazil.

${ }^{2}$ Purina Nutrição Animal. São Paulo, SP, Brazil.

${ }^{3}$ Pie Medical. Masstrich, The Netherlands.

${ }^{4}$ Laboratórios Pfizer. Guarulhos, SP, Brazil.

${ }^{5}$ MSD Saúde Animal. São Paulo, SP, Brazil.

${ }^{6}$ Hertape Calier Saúde Animal S/A. Juatuba, MG, Brazil.

${ }^{7}$ Eurofarma Laboratórios S.A. Ribeirão Preto, SP, Brazil.

Acknowledgements. Authors would like to acknowledge the Coordenação de Aperfeiçoamento de Pessoal de Nível Superior (JCFS, MTM) and Fundação de Amparo à Ciência e Tecnologia do Estado de Pernambuco (PSN) for fellowship support during the study.

Ethical approval. The research was approved by the Ethics Committee for Animal Research at Universidade Federal Rural de Pernambuco (License: 011/2013).

Declaration of interest. The authors declare that they have no conflict of interest and are available to provide any clarification.

\section{REFERENCES}

1 Alvarenga M.A., Carmo M.T. \& Landim-Alvarenga F.D.C. 2008. Superovulation in mares: limitations and perspectives. Pferdeheilkunde. 24(1): 88-91.

2 Awan F.S., Mehmood M.U., Sattar A. \& Ahmad N. 2016. Comparative efficacy of hCG or GnRH analogue (lecirelin acetate) on follicular dynamics, degree of endometrial edema, sexual behavior, ovulation and pregnancy rate in crossbred broodmares. Journal of Equine Veterinary Science. 41: 71-72.

3 Azevedo M.V., Souza N.M., Ferreira-Silva J.C., Batista I.O., Moura M.T., Alvarenga M.A., Oliveira M.A.L. \& Lima P.F. 2015. Induction of multiple ovulations in mares using low doses of GnRH agonist Deslorelin Acetate at 48 hours after luteolysis. Pferdeheilkunde. 31(2): 160-164.

4 Azevedo M.V., Souza N.M., Ferreira-Silva, J.C., Batista I.O., Sales, F.A.B.M., Alvarenga M.A., Oliveira M.A.L. \& Lima P.F. 2014. Indução de ovulações duplas utilizando baixa dose de deslorelina em éguas. Ciência Veterinária nos Trópicos. 17(1/2): 42-47. 
5 Barbacini S., Zavaglia G., Gulden P., Marchi V. \& Necchi D. 2000. Retrospective study on the efficacy of hCG in an equine artificial insemination programme using frozen semen. Equine veterinary education. 12(6): 312-317.

6 Barrier-Battut I., Le Poutre N., Trocherie E., Hecht S., des Raux A.G., Nicaise J.L., Vérin X., Bertrand J., Fiéni F., Hoier R., Renault A., Egron L., Tainturier D. \& Bruyas J.F. 2001. Use of buserelin to induce ovulation in the cyclic mare. Theriogenology. 55(8): 1679-1695.

7 Bergfelt D.R. \& Adams G.P. 1999. Ovulation synchrony after follicle ablation in mares. Journal of reproduction and fertility. 56(Suppl): 257-269.

8 Bohme P., Fonseca F.A., da Motta V.A.F. \& Espeschit C.J.B. 1992. Eficácia do HMG, HCG e PGF2 alfa na indução ou antecipação da ovulação em éguas durante o cio do potro. Revista Brasileira de Zootecnia. 21(1): 16-22.

9 Camillo F., Vannozzi I., Tesi M., Sabatini C., Rota A., Paciolla E. \& Panzani D. 2014. Induction of ovulation with buserelin in jennies: In search of the minimum effective dose. Animal Reproduction Science. 151(1): 56-60.

10 Carluccio A., Panzani S., Tosi U., Faustini M., De Amicis I. \& Veronesi M.C. 2007. Efficacy of hCG and GnRH for inducing ovulation in the jenny. Theriogenology. 68(6): 914-919.

11 Cuervo-Arango J. \& Newcombe J.R. 2010. Cloprostenol in equine reproductive practice: something more than a luteolytic drug. Reproduction in Domestic Animals. 45(5): 1262-1267.

12 Duchamp G., Bour B., Combarnous Y. \& Palmer E. 1986. Alternative solutions to hCG induction of ovulation in the mare. Journal of Reproduction and Fertility. 35: 221-228.

13 Farias L.D., Neves A.P., Rechsteiner S.M.D.E.F. \& Tarouco A.K. 2016. Indução da ovulação em éguas: uma revisão. Revista Brasileira de Reprodução Animal. 40(1): 17-21.

14 Fathalla M., Younis L. \& Jawad N. 1988. Progesterone concentration and ovascan reading during the estrous cycle in Arabian mares. Journal of Equine Veterinary Science. 8(4): 326-328.

15 Ginther O.J. 1993. Major and minor follicular waves during the equine estrous cycle. Journal of Equine Veterinary Science. 13(1): 18-25.

16 Ginther O.J., Beg M.A., Gastal E.L., Gastal M.O. \& Cooper D.A. 2009. Treatment with human chorionic gonadotropin (hCG) for ovulation induction is associated with an immediate $17 \beta$-estradiol decrease and a more rapid LH increase in mares. Animal Reproduction Science. 114(1): 311-317.

17 Harrison L.A., Squires E.L. \& McKinnon A.O. 1991. Comparison of hCG, buserelin and luprostiol for induction of ovulation in cycling mares. Journal of Equine Veterinary Science. 11(3): 163-166.

18 Henneke D.R., Potter G.D., Kreider J.L. \& Yeates B.F. 1983. Relationship between condition score, physical measurements and body fat percentage in mares. Equine Veterinary Journal. 15(4): 371-372.

19 Katila T. 2003. Effects of hormone treatments, season, age and type of mares on ovulation, twinning and pregnancy rates of mares inseminated with fresh and frozen semen. Pferdeheilkunde. 19(6): 619-624.

20 Leal Fonseca F.C.V., Jacob J.C.F., André M., Sá F., Dutra G.A., Guerson Y.B. \& Jesus V.L.T. 2016. Efeito do uso de dinoprost trometamina sobre a taxa de gestação em éguas Mangalarga Marchador. Revista Brasileira de Medicina Veterinária. 38(Suppl 2): 164-168.

21 McCue P.M., Magee C. \& Gee E.K. 2007. Comparison of compounded deslorelin and hCG for induction of ovulation in mares. Journal of Equine Veterinary Science. 27(2): 58-61.

22 McKinnon A.O., Nobelius A.M., Figueroa S., Skidmore J., Vasey J.R. \& Trigg T.E. 1993. Predictable ovulation in mares treated with an implant of the GnRH analogue deslorelin. Equine Veterinary Journal. 25(4): $321-323$.

23 Metcalf E.S. \& Thompson M.M. 2010. The effect of PGF2 $\alpha$-induction of estrus on pregnancy rates in mares. Journal of Equine Veterinary Science. 30(4): 196-199.

24 Monahan M.W., Amoss M.S., Anderson H. \& Vale W. 1973. Synthetic analogs of the hypothalamic luteinizing hormone releasing factor with increased agonist or antatonist properties. Biochemistry. 12(23): 4616-4620.

25 Nagao J.F., Neves Neto J.R., Papa F.O., Alvarenga M.A., Freitas-Dell'Aqua C.P. \& Dell'Aqua J.A. 2012. Induction of double ovulation in mares using deslorelin acetate. Animal Reproduction Science. 136(1): 69-73.

26 Newcombe J.R. \& Cuervo-Arango J. 2017. What Are the Options for Induction of Ovulation in the Mare in Europe? Buserelin as an Alternative to Human Chorionic Gonadotropin. Journal of Equine Veterinary Science. 51: 8-17.

27 Newcombe J.R. \& Cuervo-Arango J. 2016. Comparison of the efficacy of different single doses of buserelin with hCG for timed ovulation induction in the mare. Journal of Equine Veterinary Science. 41: 57. 
28 Newcombe J.R. \& Cuervo-Arango J. 2011. The effect of time of insemination with fresh cooled transported semen and natural mating relative to ovulation on pregnancy and embryo loss rates in the mare. Reproduction in Domestic Animals. 46(4): 678-681.

29 Newcombe J.R., Jöchle W. \& Cuervo-Arango J. 2008. Effect of dose of cloprostenol on the interval to ovulation in the diestrous mare: a retrospective study. Journal of Equine Veterinary Science. 28(9): 532-539.

30 Pinto M.R., Miragaya M.H., Burns P., Douglas R. \& Neild D.M. 2017. Strategies for Increasing Reproductive Efficiency in a Commercial Embryo Transfer Program With High Performance Donor Mares Under Training. Journal of Equine Veterinary Science. 54: 93-97.

31 Preacher K.J. 2001. Calculation for the chi-square test: An interactive calculation tool for chi-square tests of goodness of fit and independence. Computer software. [Fonte: http://quantpsy.org]. [Accessed online in March 2017].

32 Rodrigues T.G., Caiado J.R.C., Fagundes B. \& Straggiotti J.F.S. 2015. Uso de progesterona de longa acao e inovulacao de eguas no segundo dia após a ovulação. Acta Biomedica Brasiliensia. 3(1): 14-26.

33 Roser J.F., Kiefer B.L., Evans J.W., Neely D.P. \& Pacheco C.A. 1979. The development of antibodies to human chorionic gonadotrophin following its repeated injection in the cyclic mare. Journal of Reproduction and Fertility. 27: 173-179.

34 Samper J.C. 2008. Induction of estrus and ovulation: why some mares respond and others do not. Theriogenology. 70(3): 445-447.

35 Squires E.L. 2008. Hormonal manipulation of the mare: a review. Journal of Equine Veterinary Science. 28(11): 627634.

36 Squires E.L. \& McCue P.M. 2007. Superovulation in mares. Animal Reproduction Science. 99(1): 1-8.

37 Sullivan J.J., Parker W.G. \& Larson L.L. 1973. Duration of estrus and ovulation time in nonlactating mares given human chorionic gondotropin during three successive estrous periods. Journal of the American Veterinary Medical Association. 162(10): 895-898.

38 Taveiros A.W., Melo P.R.M., Freitas Neto L.M., Aguiar Filho C.R., Silva A.C.J., Lima P.F. \& Oliveira M.A.L. 2008. Produção de embriões de éguas Mangalarga Marchador utilizadas nas Regiões Nordeste e Sudeste do Brasil. Medicina Veterinária (UFRPE). 2(3): 19-24.

39 Voge J.L., Sudderth A.K., Brinsko S.P., Burns P.J. \& Blanchard T.L. 2012. Comparison of efficacy of two dose rates of histrelin to human chorionic gonadotropin for inducing ovulation in broodmares. Journal of Equine Veterinary Science. 32(4): 208-210.

40 Wilson C.G., Downie C.R., Hughes J.P. \& Roser J.F. 1990. Effects of repeated hCG injections on reproductive efficiency in mares. Journal of Equine Veterinary Science. 10(4): 301-308. 